\title{
OBSERVATIONS ON HISTORICAL TERMINOLOGY: GROTTE AND HÖHLE IN GERMAN TEXTS
}

\section{POGLED V ZGODOVINO TERMINOLOGIJE: GROTTE IN HÖHLE V NEMŠKIH BESEDILIH}

\author{
BRIGITTA MADER ${ }^{1}$
}

1 Kriehubergasse 25/11 AT-1050 WIEN (Austria) -

Via Cordaroli, 26 I-34135 TRIESTE (Italia) 


\section{Abstract}

UDC: $551.44: 001.4$

\section{Brigitta Mader: Observations on historical terminology: Grotte and Höhle in German texts.}

The author treats the historical terminology for caves (Grotte, Höhle) used by German speaking authors and explorers in the Austro-Hungarian period with special emphasis on the etymology of the terms Grotte and Höhle, coming to the conclusion that those terms do not indicate a difference either from the speleological point of view or the linguistic one. The contemporary use of Grotte and Höhle in the Austro-Hungarian period is determined by linguistic conditions and influence of the Italian (bilingual or even trilingual situation) in the classical Karst region.

Key words: karst terminology, Grotte, Höhle, Kras.

Izvleček

UDC: 551.44:001.4

\section{Brigitta Mader: Pogled v zgodovino terminologije: Grotte in Höhle v nemških besedilih}

Avtor govori o zgodovini terminologije za jame (Grotte, Höhle), ki so jo uporabljali nemško govoreči pisci in raziskovalci v avstrogrskem času, s posebnim poudarkom na etimologiji izrazov Grotte in Höhle. Sklene, da ni razlike med njima, ne s speleološkega in ne z jezikoslovnega vidika. Sočasna raba obeh izrazov v omenjenem obdobju je bila odvisna od jezikovnih okoliščin in vpliva italijanščine (dvojezično ali celo trojezično okolje) na klasičnem Krasu.

Ključne besede: kraška terminologija, Grotte, Höhle, Kras. 
In 1912 we find an announcement for the caves of Postojna, mentioned in the German language as Adelsberger Grotte. (Fig.1) Having a look at various German written traveller's guides published in the 19th century, the word Grotte is very frequent and used not only for cave-names but also as German term indicating a cave. So we have: Riesengrotte bei Opcina Triest (Fig.2), Kleinhäuslergrotte, Kronprinz Rudolf-Grotte, Grotte von Corgnale and also Tropfsteingrotte, Grottenfest, Grotteneingang, Grotten des Karsts, Grottenwelt etc. (Fig.3).

But we also find Grotten und Höhlen von St. Canzian (Tominzgrotte, Schmidlgrotte, Rekahöhle...) and in the description of the Adelsberger Grotte some of the parts of the cave system are denominated Höhle. For example: Poikhöhle together with Ferdinandsgrotte, Erzherzog Johann Grotte, Alte Grotte, Löwengreif-Grotte. And we find also Höhlen von Luegg, Höhlenschloß von Luegg.

So there is the question: does there exist any difference between Grotte and Höhle? And if there is a difference, in what does it consist? Are there two different meanings, two different types of caves?

There is obviously a question which was treated already in the 19th century, as we can see in the work of Adolf Schmidl, Wegweiser in die Adelberger Grotte und die benachbarten Höhlen des Karst nach neuen Untersuchungen in den Jahren 1850-1852. published in Vienna in 1853.

Giving in the introduction a general explanation of the Karst and Karstphenomena, Schmidl tries also to define Grotte and Höhle on the basis of two different characteristics: water and stalactites. In his opinion Höhlen are long subterranean water channels. On the contrary Grotten are no longer occupied by running water. They are probably channels of former rivers, which have now a deeper course. In the Grotten we find only some pools of water. Höhlen usualy do not have stalactites and if only a few. Grotten do have a lot of stalactites (Schmidl1853).

This is a definition which is not accepted at all by the modern speleologists. In the speleological dictionary published in 1965 in Vienna the denomination Grotte for a cave with particularly rich stalactite decorations is considered as "inadmissible". Kyrle proposed to use the term Grotte only for artificial caves and considered the historical distinction of Höhle and Grotte as "senseless" (Trimmel 1965 following Kyrle 1923).

The geological dictionary, published for the first time in 1957 in Stuttgart, gives a less strict interpretation for the term Grotte, which might be a natural as well as an artificial cave. Grotte is used sometimes as a synonym for Höhle and sometimes Grotte indicates also a vaulted cave without much depth. Höhle is defined by the geological dictionary as a "natural subterrenean stone-hollow filled in part or entirely with gas, liquid or solid material" (Murawski 1983).

Following this interpretation is the encyclopedic handbook to the prehistory of Europe (Enzyklopädisches Handbuch zur Ur- und Frühgeschichte Europas) citing only the catchword Höhle. In this handbook special attention is paid to the karst caves. The formation of sinterforms or stalactites is mentioned as one of the "autoctone components" of Karst-caves (Filip 1966).

Kyrle's definition of Grotte, specially in the modern German, as designation for an artificial cave is mainly based on the fact that artificial cave constructions - usualy built and used as a romantic element in Mannerism garden architecture - are very often decorated with stalactites (Trimmel 1965). 
In Hübner and Zinken's Curienses und Reales Natur-Kunst-Berg-Gewerck und Handlungslexikon, published in Leipzig in 1762, we find a similar definition of Grotte as a subterranean construction and imitation of natural caves in pleasure gardens to obtain an area with cool air (Waldner 1940/41).

For this reason Grotte became also a term indicating an artificial rock cave, which in most cases has also a fountain (Wörterbuch Architektur 1996).

Concerning the contrast between natural formation and artificial construction, the German dictionary gives less strict definitions for Grotte and Höhle: Grotte is a rock cave of little depth, but might be also an artificial construction in garden architecture. Höhle is a natural hollow in stone or in a tree with a relative small access (Wahrig 1985).

The Allgemeine Realencyclopädie oder Conversationslexikon für alle Stände published in Regensburg (1869) mentions Grotte as a natural as well as an artificial cave and indicates the mythological signification of Grotte as , symbol of the world and of the secret action of nature

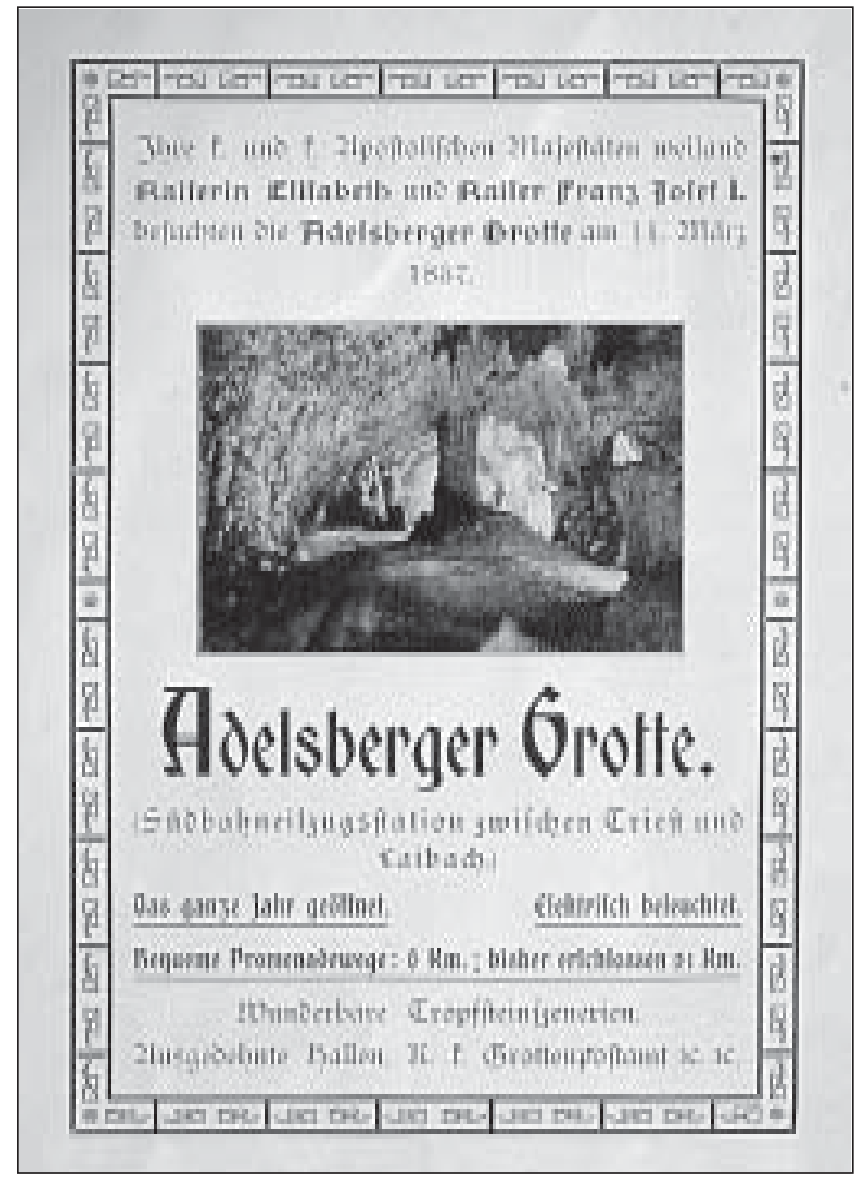

Fig. 1: Historical poster "Adelsberger-Grotte". and their deities", for example: Pascht, Mithras, Kalypso, Eileithya-Artemis and the Nymphs, who all found adoration in caves in ancient times. Nympheums caves specially dedicated to the Nymphs - were in the period of Mannerism rebuilt as elements of garden architecture.

So, for getting a clearer idea about the signification of Höhle and Grotte it seems necessary to have a look to the etymology of those words.

Höhle is an abstract from the adjectiv "hohl" (hollow) to the Old- and -Middle high German "hol" in the meaning of "hollow, cave, concav, hole, aperture" coming from the Germanic *hula (Kluge 1989). Grotte significates "rock cave" and was taken in the $15^{\text {th }}$ century from the Italian into the German language (Kluge 1989).

The etymology of the 
Italian "grotta" goes back to the late latin "crupta, crypta", a Grecism from architecture-terminology, which indicated "every covered and subterranaen locality". This context has been conserved in the meaning of "grotta" as subterranean room used as pantry or larder of an inn, but the main signification linguistically evidenced already at the beginning of the 14th century is "a natural cave usualy in limestone rock formed by water" (Cortelazzo, Zolli 1884).

In modern Italian "Grotta" is still in use. In some alpine idioms "grotta" indicates not only Höhle (cave) but also a rocky area and also "Karrenfelder" (Hubschmid 1951).Interesting also is the form "grotto" used in Tuscany, because we find the same word also in historical descriptions of caves in the English language (Shaw 2000).

In modern German Höhle is the corresponding term for the Italian "grotta". Grotte is nowadays no more used for caves.

But having a look at historical German texts we note that the term Grotte is the more frequent the further back we go. Valvasor for example regularly uses Grotte and not only for the "berühmte

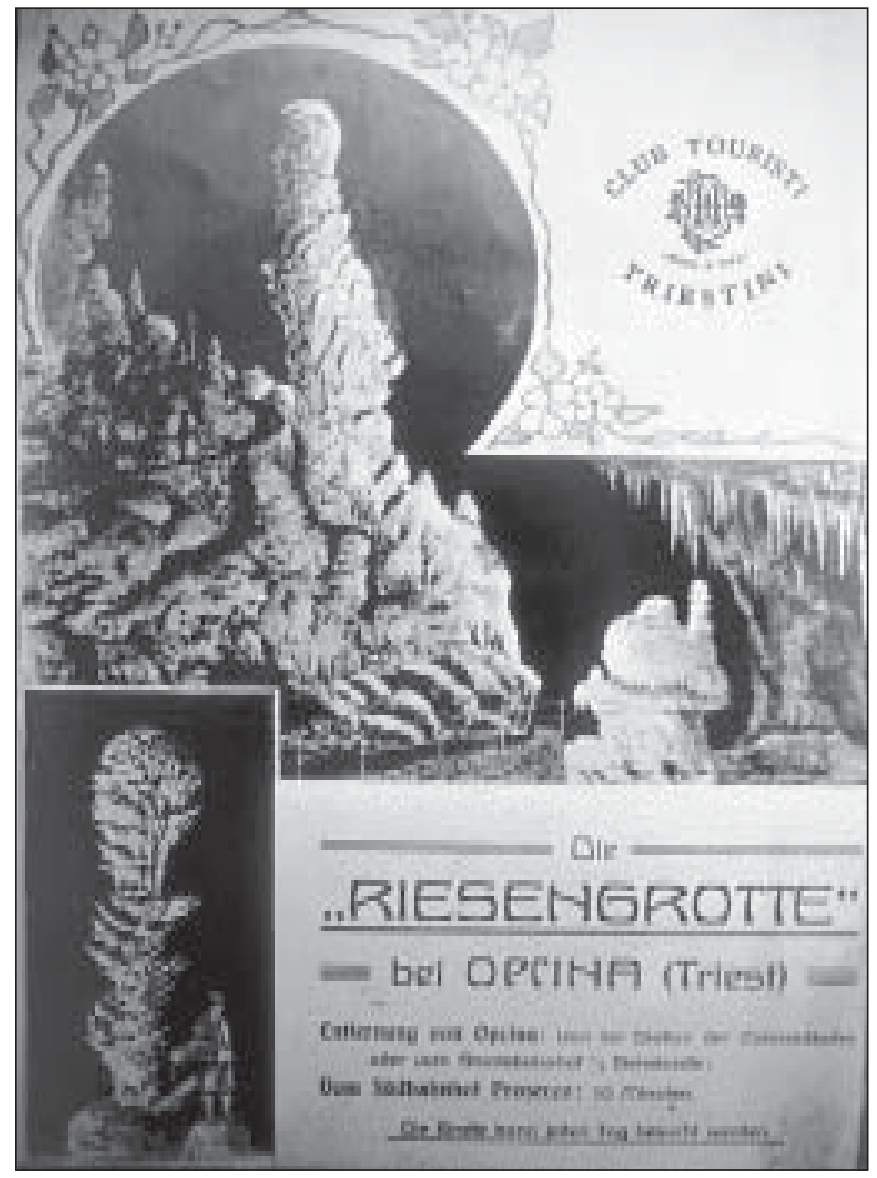

Fig. 2: Historical poster "Riesengrotte bei Trieste".
Grotte von Adelsberg" but also for other caves, mentioning for example the "Grotten in the 5th part of Carniola in the Učka mountain system in Istria" (1689). Besides of Grotte Valvasor also uses the terms Höle and Speluncke. Spelunca we find even earlier in Italian texts (M.Nicolo di Gozze in 1585; Malez 1984). In Italian "spelonca" indicates "a big wide, huge and profound cave" (Cortelazzo 1988); in German it is used in figurative sense of "zwielichtige Gaststätte" "obscure inn" (Kluge 1989). But Valvasor used "Speluncke" not in the German meaning but as synonym for Höhle; he also uses Grotte as a synonym for Höhle.

So, the terminological question about the meaning of Höhle and Grotte does not seem anymore a speleological problem, but 
rather a linguistic one. A conclusion which is determined first by the etymology of the Italian word "grotta" as "a natural cave usualy in limestone formed by water" and second by the fact, that all linguistic forms and cave-names made with Grotte in the German language chiefly concern the classical and Dalmatian Karst regions, which are very influenced by the Italian language. Beyond it are those areas which just in the period of the beginning of intense cave explorations were under the Austro-Hungarian dominion. Specially the Austrian German language has for historical-political reasons a very rich vocabulary with romance origins.

The linguistic interpretation of Grotte:Höhle as synonyms finds also support in the works of Karl L. Moser, who is - apart from cave names formed with Grotte - consequently using only Höhle, allthough he is mainly treating Karst caves in the sourroundings of Trieste (Moser 1899). Moser came from Teschen in the Austrian part of Slesia, studied in Vienna and did not grow up in a bi- or even trilingual situation as occurs in the Austrian littoral or in Dalmatia.

The synonym hypothesis is also confirmed by two bilingual persons : Carlo Marchesetti, botanist, prehistorian and director of the Trieste Natural history Museum, and Ludwig Salvator, Austrian Archduke and natural scientist with much cave experience, but mostly known for having invited Edouard Alfred Martel to explore the caves of Mallorca (Mader 1994).

Marchesetti uses Höhle when writing in German and grotta when writing in Italian. Ludwig Salvator also uses grotta in Italian, but in his German descriptions of caves he uses Höhle and Grotte as synonyms, because he wanted to avoid for stylistic reasons repeating the same word several times (Mader 1994, 1998, 2001; Ludwig Salvator 1897, 1904).

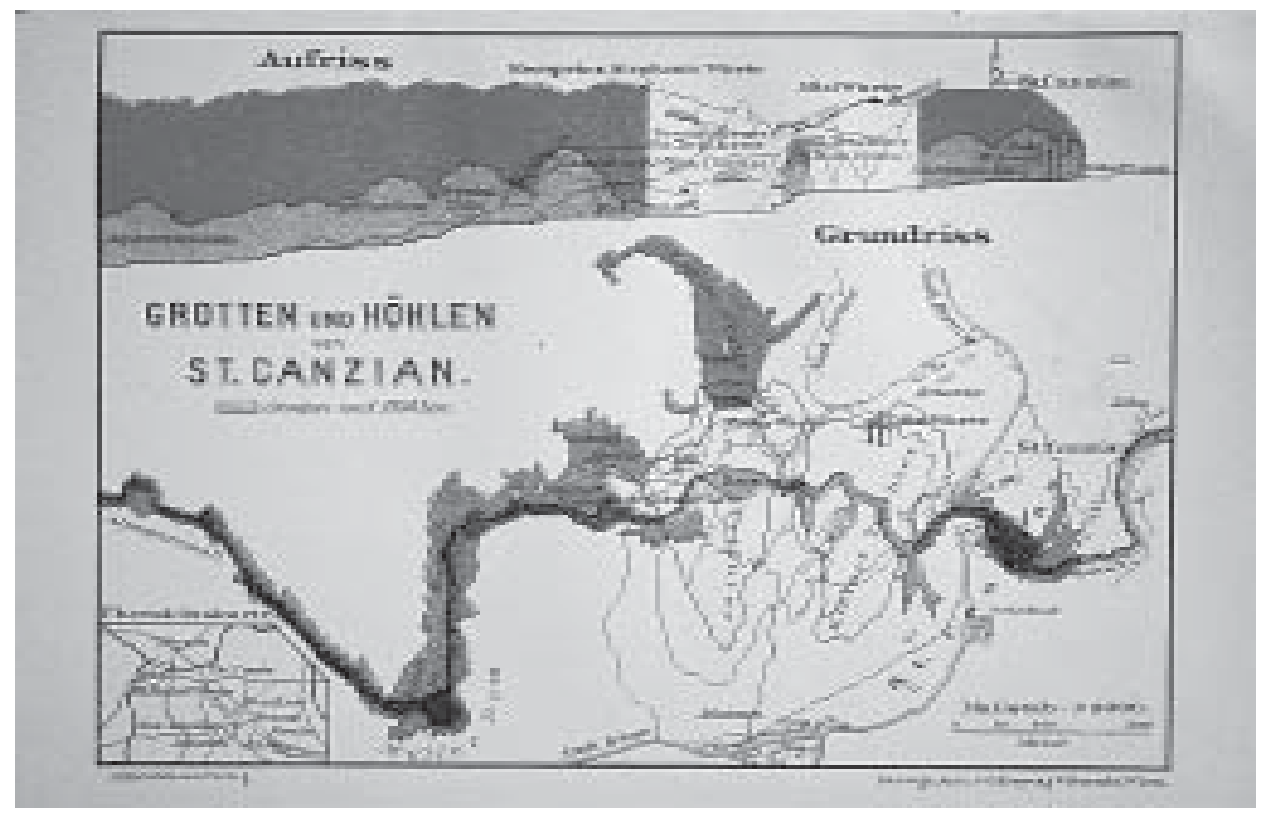

Fig. 3: Historical tourist-guide: Illustrirter Führer durch Triest und Umgebung. Hartleben's Illustrirter Führer Nr.10, III.Auflage, Wien-Pest-Leipzig 1892, p.82-83. 
Parallel to the continuing development of speleology and speleological archeology, also done in other regions and European countries, the term Höhle became more and more dominant in the German language and in German written scientific texts. So, for example, Moritz Hoernes uses only Höhle in his work Die Urgeschichte des Menschen (1896) and in the same way Gundacker Graf Count Wurmbrandt speaks only about Höhlen in his chapter about the prehistoric period in Istria in the Österreichisch-ungarische Monarchie in Wort und Bild. (1891).

In conclusion we consider the contemporary use of Höhle and Grotte in German-written historical texsts as a linguistic phenomenon which is a result of specific conditions caused by the historical-political situation and linguistic influence of the Italian, but does not have any signification concerning type or form of caves.

\section{ACKNOWLEDGMENTS}

The author thanks very much Karl Mais of the Vienna Natural history Museum for providing speleological bibliographic material and Trevor R. Shaw of the Karst Research Institute (Slovenian Academy of Sciences and Arts) in Postojna for the linguistic correction of the paper.

\section{REFERENCES}

Bach, A., 1953: Deutsche Namenkunde II, Die deutschen Ortsnamen 1. p.256, Heidelberg

Cortelazzo, M., Zolli, P., 1984: Dizionario etimologico della lingua Italiana. 2/D-H. p.524; 1988: 5/S-Z. p.124f. Bologna

Doria, M., 1985: Note di speleonomastica Carsica. Studi linguistici e filologici per Carlo Alberto Mastrelli. p. 153, Pisa

Filip, J., 1966: Enzyklopädisches Handbuch zur Ur- und Frühgeschichte Europas. Band I (A- K). p.493, Stuttgart-Berlin-Köln-Mainz

Hoernes, M., 1896: Die Urgeschichte des Menschen.Wien-Pest-Leipzig

Hubschmid, J., 1951: Alpenwörter romanischen und vorromanischen Ursprungs. p.17, Bern

Kluge, F., 1989: Etymologisches Wörterbuch der deutschen Sprache.p.280,313,683, Berlin- New York

Kyrle, G., 1923: Grundriß der theoretischen Speläologie. p.12, Wien

Lexer, M., 1972: Matthias Lexers Mittelhochdeutsches Taschenwörterbuch. p.91, Stuttgart

Ludwig Salvator, 1897: Die Balearen-Geschildert in Wort und Bild. 1-2.Würzburg-Leipzig; 1898: Alboran. Prag; 1904: Zante. Specieller Theil. Prag.(here are only a few selected works citated)

Mader, B., 1994: E. A. Martel in Briefen an Carlo Marchesetti und Erzherzog Ludwig Salvator. Acta Carsologica 23. p. 178 - 190, Postojna

Mader, B., 1998: “Mi creda sempre suo aff. A. Luigi Salvatore ecc.” L'Arciduca Lodovico Salvatore e la sua presenza a Trieste, quale risulta dalla sua corrispondenza con Carlo de Marchesetti. Annales - Annals for Istran and Mediterranean Studies, series historia et sociologia. 14. p.141-164, Koper

Mader, B., 2001: Karst and Caves in the works of the Austrian Archduke and natural scientist Ludwig Salvator. I. The Region of Quarnero (Kvarner). Acta Carsologica 30/1.p.156179, Postojna 
Malez, M., 1984: Povijest speleoloških istra•ivanja u Hrvatskoj in: Deveti Jugoslavenski Speleološki Kongres 1984. Zbornik predavanja. p.73-102, Zagreb

Moser, K.L., 1899: Der Karst und seine Höhlen.Triest

Murawski, H., 1983: Geologisches Wörterbuch. p.89, 95, Stuttgart (dtv)

Realencyklopädie, Allgemeine, oder Conversationslexikon für alle Stände. 1869: 7.Bd. Regensburg (catchword: Grotte)

Schmidl, A., 1853: Wegweiser in die Adelberger Grotte und die benachbarten Höhlen des Karst nach neuen Untersuchungen in den Jahren 1850-1852. p.XII, Wien

Shaw, T.R., 2000: Foreign Travellers in the Slovene Karst 1537-1900. Ljubljana

Trimmel, H., 1965: Speläologisches Fachwörterbuch. p.30,Wien

Valvasor, J.W., 1689: Die Ehre des Herzogthums Krain. I-IV. Laibach-Nürnberg

Wahrig, G., 1985: dtv Wörterbuch der deutschen Sprache. p.367, 419, München

Waldner, F., 1940/41: Die Höhlennamen in den deutschen Alpen. Mitteilungen der Höhlen- und Karstforschung. p.136, Berlin

Wörterbuch der Architektur, Kleines., 1996, p.57, Stuttgart (Reclam)

Wurmbrandt, G., 1891: Zur Vorgeschichte Istriens: Die prähistorische Zeit. in: Die Österreichischungarische Monarchie in Wort und Bild. p.125-128, Wien 